\title{
The Hudson Bay Railroad
}

\section{How Canada Will Eliminate the Railroad Haul Across Half the Continent}

By Earle William Gage

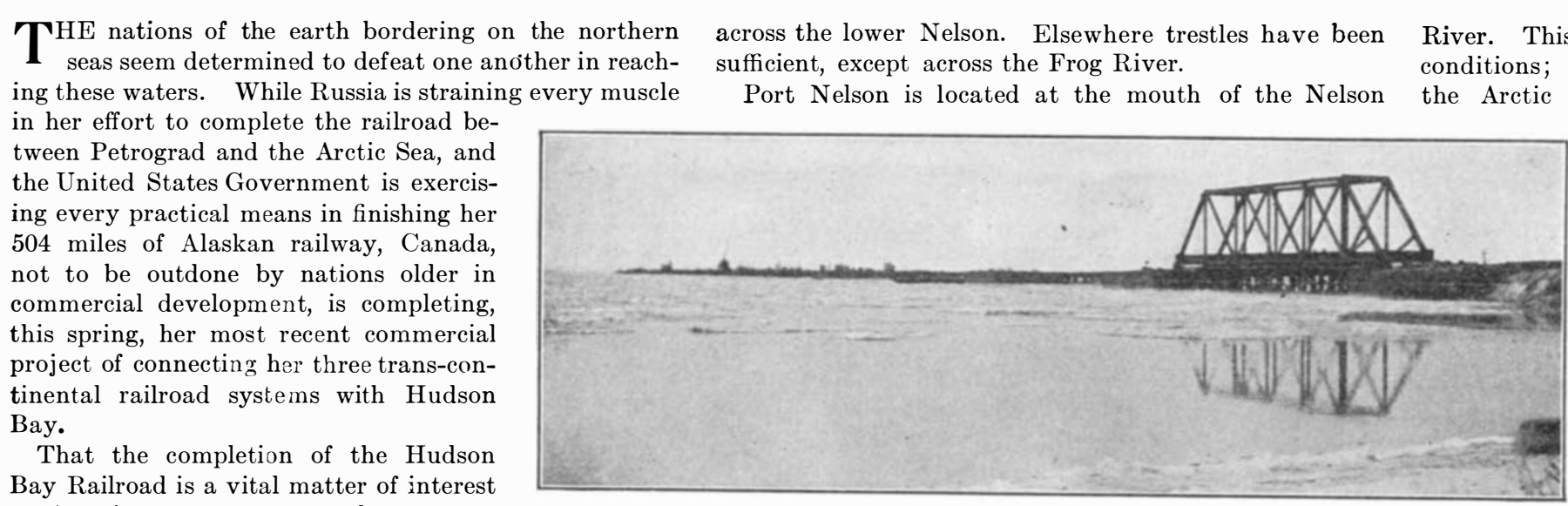
road is a vital matter of interest to American commerce, needs no argupassenger agent desiring a new field of tourist endeavor, but the result of insistent demands made by a country whose development has outstripped the efforts of three great railway systems to keep pace. As early as 1906, Western Canada was the congested center of railway transportation, both outgoing and incoming lines being blocked with grain live stock and supplies. The Hudson Bay Railroad is simply the result of a continuous blockade of traffic, the aim being to relieve this by giving the shortest possible route to tide water from fields of production.

Had not an enlarged outlet been supplied to the ocean, the development of Canada would have been retarded Canada's great inland sea, Hudson Bay, gives the West tidewater in the meridian of the Mississippi Valley. A glance at the map shows it to be the shortest route from the center of the country's fields of production to the world's markets. Port Nelson, the northern terminus of the new railroad, is as near the central point of the grain area a the center of that area is to the head of the Great Lakes, and it is about the same distance from Liverpool as Montreal.

When the engineers of the Canadian Northern Railway drove the last spike at The Pas, they had forged the first link in the new commercial chain. Thi was the initial effort to reach Hudso Bay. In 1908 the Department of Rail ways and Canals of the Dominion Government sent Engineer John Armstrong, an experienced railway surveyor, with a staff of four parties, to make the purposed survey map to Hudson Bay from The Pas, which is located on the River Saskatchewan. Lines were run from this point to Fort Churchill and to Port Nelson, both on Hudson Bay; contours were taken closely enough to enable a projected location to be made that assured reasonably accurate quantitics, and detailed surveys were made of the harbors of both points on the bay, as weil as at all important river crossings. A Port Nelson promised the most accessible port for commercial purposes, with exceptionally favorable terminal grounds and pier foundations, it was selected as most favorable. While it would have been 480 miles to Fort Churchill, the line as laid down will be but 425 miles long. Moreover, it passes through a country rich in natural resources, and affords a much more reasonable location for a roadbed, with the fewest possible excavations.

In fact, the first section of approximately 120 miles is through a comparatively level or smooth country, affording easy grades and cheap construction. The stream crossings are very light, with the exception of the River Saskatchewan. The second section of 120 miles is through a granite country, demanding rockcutting in roadbed construction. One large bridge has been constructed across the Nelson River at Manitou Rapids, 1,000 feet wide, and one of 3,000 feet
General view of Port Nelson pier; first span of bridge nearly completed

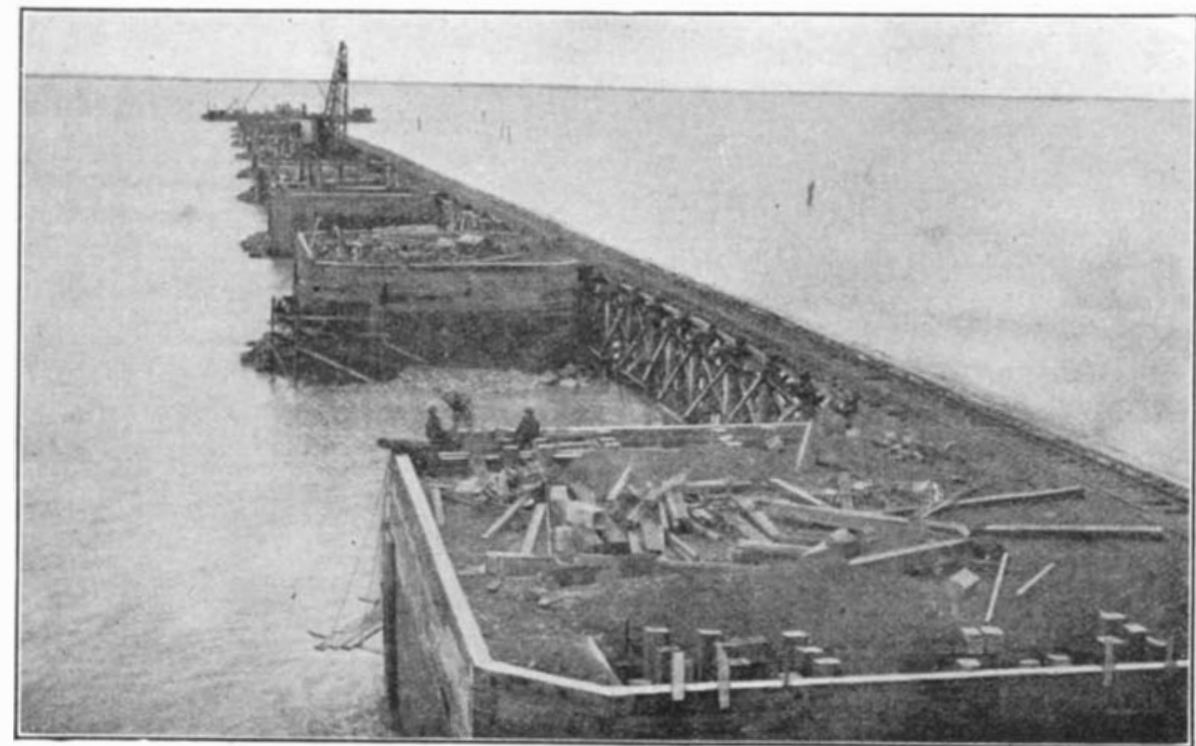

Looking toward new Hudson Bay ship channel, showing work in progress on bridge piers. In the foreground, hardwood and steel plate ice bulkheads are being placed

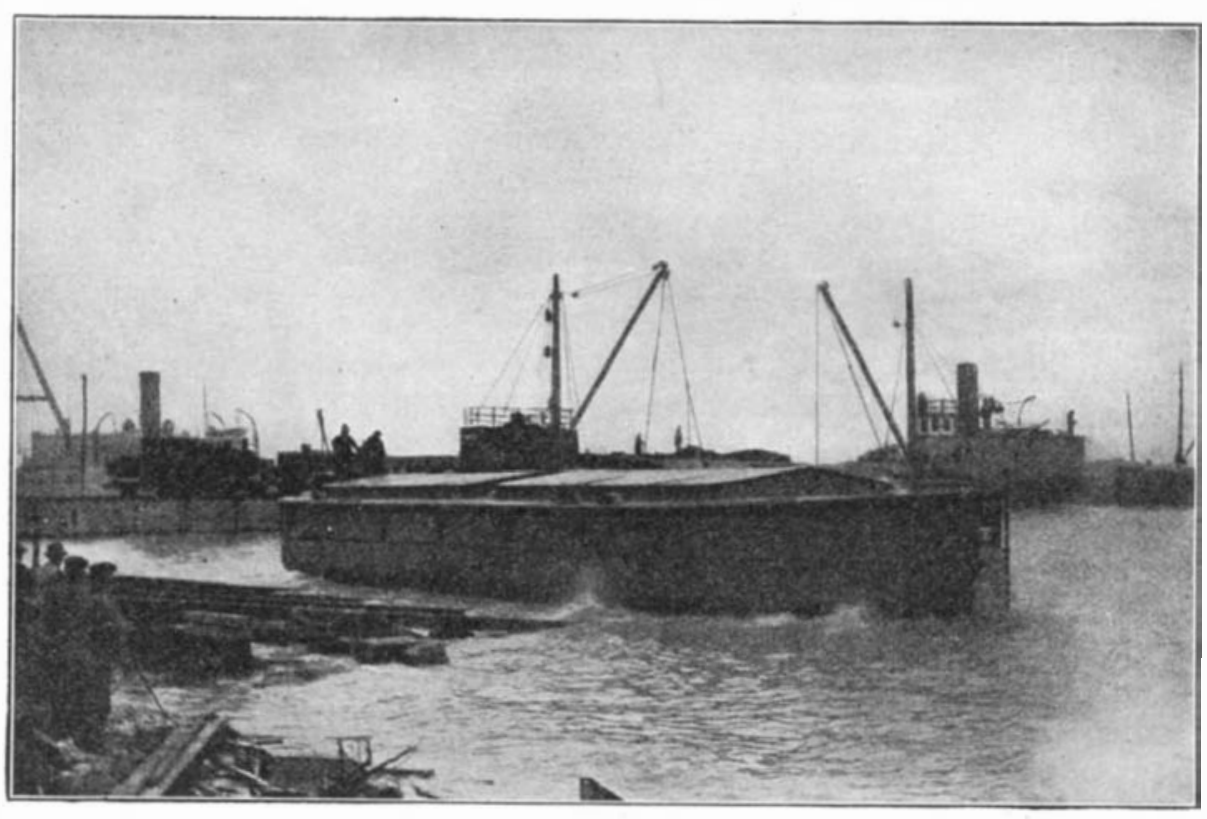

Steel tow barge at Port Nelson

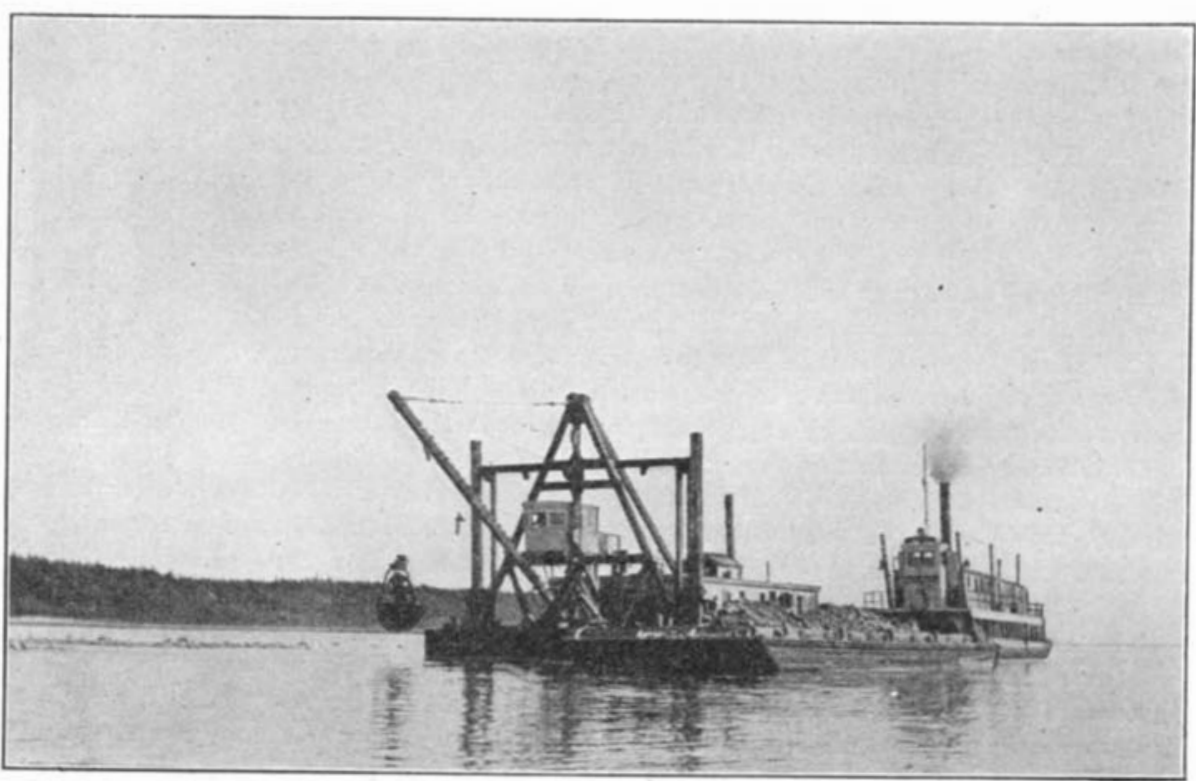

Excavating boulders at Port Nelson from river bed to use for crib filling. Orangepeel dredge, scows, and sternwheel tug were built at Port Nelson region is often associated with Arctic no part of Hudson Bay comes within rcle, and Engineer Armstrong in his recommendations stated with considerable assurance "That ships may enter and leave Port Nelson all the year round is a fact worth remembering." The northern part of the Bay is in about the same latitude as the Highlands of Scotland, while Moose Factory, on the southern shore, is considerably north of London. Port Nelson is south of Riga, Russia's great seaport, on the Baltic, and Fort Churchill on about the same parallel as Stockholm. The temperature of the water of the Bay is several degrees higher than that of Lake Superior, and in the opinion of Commander Gordon, the Bay may be regarded as a vast basin of comparatively warm water, which has a mitigating influence on the winter climate of the surrounding country.

Though the Bay remains open, Hudson Strait freezes over. Hence transportation will be possible for only three months a year, from the end of July to about the end of October. But inasmuch as this gives full time for the moving of the food products to Europe, at a very material saving in time and freight cost, the expenditure of $\$ 16,000,000$ for the construction of the 425 miles of railroad, will pay big dividends to the government. During the closed season the natural resources of the Bay region, including farm crops, timber, paper-pulp, minerals, and the enormous wealth of fur and fin, will compensate for the operation of the system.

The exponents of the railroad point out that the heavy grain traffic from the western plains to the Atlantic seaboard is carried over the Great Lakes only during the summer and fall season, and that it must close with the ice-jam. This is but a little longer season than the Hudson Bay route promises, and inasmuch as the waters permit large vessels to enter to Port Nelson, larger cargoes may be carried in a shorter time, which discounts the argument against the route to Europe.

That the Hudson Bay route promises a path from Western Canada to Liverpool, shorter by 1,000 miles than the present prevailing rail route, is a powerful factor in its favor. Winnipeg, Brandon, Regina, Calgary, Prince Albert and Edmonton, the great collecting points of Western Canada, are from 1,061 to 1,296 miles nearer by shortest rail routes, to Port Nelson than to Montreal. On the other hand, from Port Nelson it is 2,925 miles to Liverpool, while from Montreal, via Belle Isle the distance is 2,761 and via Cape Race 2,927 miles. The utilization of the Hudson Bay route will effect, therefore, an average shortening of 1,000 miles to the tide water, without increasing the ocean distance to the world's markets.

That a very material saving will be effected in freight cost alone, is appreciated when we remember that the freight upon grain from the wheat belt to Hudson Bay approximates ten cents per bushel, or the same as to the head of the Great Lakes, at present. It now costs fifteen cents per bushel to transport the grain to the Atlantic seaboard ports, which represents a fair profit to the wheat growers. Assuming an export trade of $20,000,000$ bushels, which could be readily handled if the harbor were open but two months of the year, this saving would amount in a single season to approximately $\$ 3,000,000$

The demand for Western Canada's prime beef, mutton, pork and poultry is increasing in Europe. It now costs about sixty cents per hundred to transport steers to the Atlantic ports, and an additional sixty cents to ship them 
to Liverpool. For the payment of 60 cents per hundred these cattle and stock may be delivered in Liverpool, on an average, from the fields of production, or an average saving of $\$ 6$ per head for steers. This saving will approximate $\$ 1,000,000$ per season of only two months, or a total of $\$ 4,000,000$. Therefore, if the Hudson Bay Railroad is operated but two out of the twelve months, in four years it would pay off its construction debt. But the officials have calculated that the remaining nine or ten months may be devoted to interest bearing operations of a local nature.

The Oil-Engined Yacht "Aramis"

WHEN the war broke in upon us there was completing at Jacob's Yard, City Island, the large and powerful yacht "Aramis" for her owner A. H. Marks. Promptly he offered her for government service in connection with patrol work, or any other duty for which she might be suitable.

The "Aramis" is, we understand, the largest yacht driven by oil engines in existence. The hull is designed somewhat on naval lines, with a modified cruiser stern, and the rudder completely below the waterline. The dimensions are, length 157 feet; beam 22 feet; draft 10 feet 9 inches. The gross tonnage is 270 and the riet tonnage $1831 / 2$ tons.

The "Aramis" is driven by two Diesel, heavy-oil engines at a speed of about twenty knots. Because of her size she could carry quite a heavy armament if it were desired; but should she be employed in the submarine-swatting service she will probably mount one or more 3-inch rapid-firers, or a large number of six and three-pounders.

A novel feature in this yacht is the installation of a Sperry gyroscopic stabilizer, which has been placed, as our illustration shows, in the engine room. The stabilizer which was installed for the comfort of the owner and his guest very valuable in making "Aramis" a steady gun platform. The stabilizer in the "Aramis" has the following particulars:

Weight of rotor Speed of rotor.

Width of face of roto

100 pounds Horse power necessary to run rotor.....7 $\mathrm{H}^{\prime} . \mathrm{P}^{\prime}$ Motor.... 3-ph. A. C. Induction spinning motor

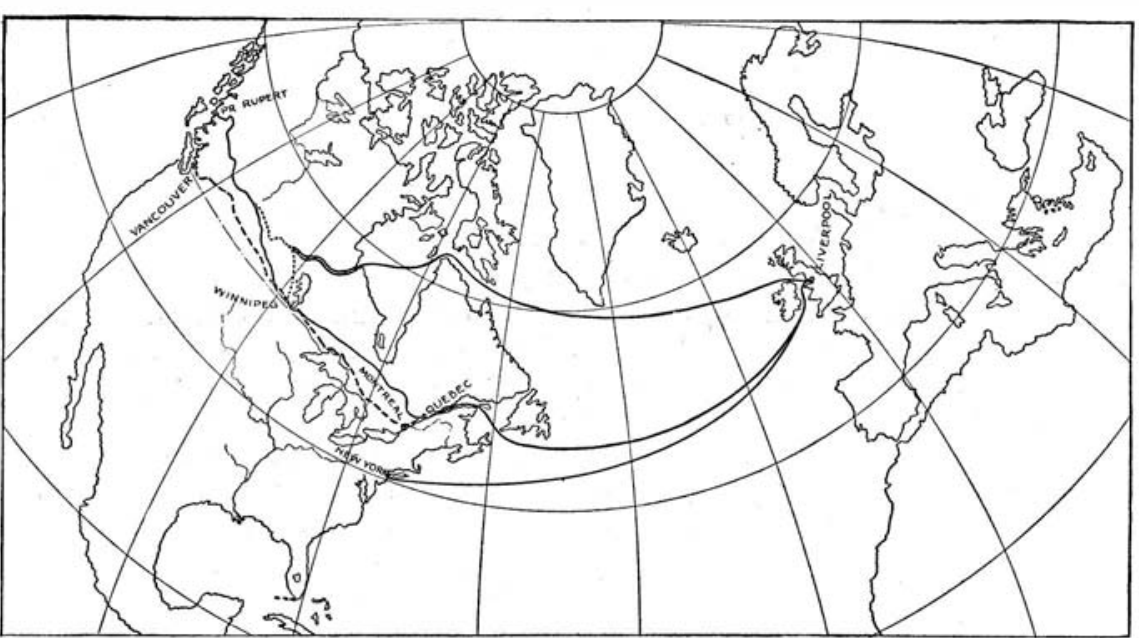

The Hudson Bay Railroad in its relation to Canada's three leading railroad The Hudson Bay Railroad is shown by double lines

action, the instant there is the slightest response of the ship to the rolling action of a wave, the little control gyro detects it, and, by its movement, closes a circuit which immediately releases a brake $B$ and starts the precession motor $\mathrm{A}$, whose function it is to rotate the main gyro about its axis. This motor, by means of the worm and wheel $\mathrm{C}$ rotates the pinion $\mathrm{D}$, which engages the large precession gear $\mathrm{E}$, and thereby turns or precesses the gyro. The turning of the main gyro brings into play a force which acts directly against the force exerted by the wave. The gyro precesses slowly until

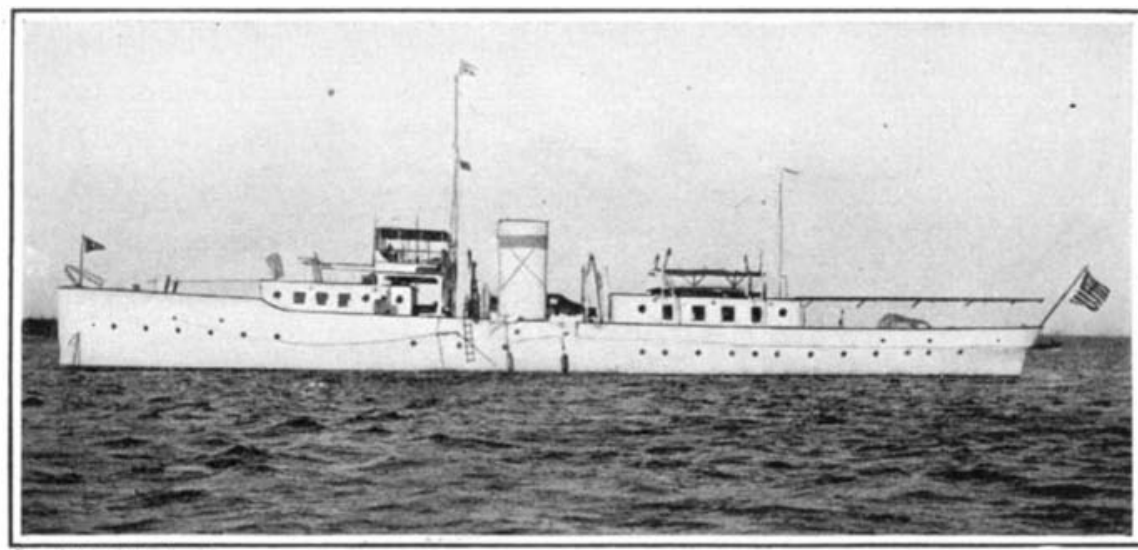

The "Aramis" driven by two Diesel, heavy-oil engines. This is the largest yacht in existence driven by oil engines. It is capable of a speed of 20 knots
This equipment, weighing about three tons, is able to hold a 250-ton boat on an even keel regardless of weather conditions. The plant consists actually of two main elements, a small auxiliary gyro and the main gyro. Before a ship can move in response to the disturbing force of a wave there is a slight lag. This time lag is utilized by means of the small gyro, which is so sensitive that it detects a roll of a fraction of a degree. The motion of the little fellow gets under way, or "premotion " of the little fellow gets une forces which exactly balance the disturbance, or tendency to movement, of the ship due to the wave. the wave has passed, when the contact of the control gyro is broken and the brake immediately set, thereby preventing further precession. The control gyro is then conditioned to detect the next wave and cause the main gyro to precess in the proper direction to oppose e rolling tendency. involved a long transportation of the ore around the Horn to Liverpool, or sometimes to Cornwall, from which places, after reduction, the metal has
The Panama Canal and the Tin Smelter

THE use of Bolivia tin in this country has always been shipped across the ocean again mostly to New York, for American distribution. But the opening of the Panama Canal has so shortened the journey from Mollendo, Peru, and from Arica and Antofagasta Chile - the chief ports used by lind-locked Bolivia in her dealings the outer world-that they are now les than half as far from New York than from the British smelters. Accordingly the best economy seems to demand that we bring the Bolivian ore directly here and do our own smelting; and this we are now about to do.

The largest European firm of tin smelters has just purchased a tract of some nin acres of land on the northern shore of Jamaica Bay, the great basin which some day is to play such a heavy role in New York's commercial development. Plans for a tin smelter on this site, which will be the largest and most modern of its kind in the world, are in preparation, and within a year this will be in actual operation. When completed and in full swing, it will have an annual output of 20,000 tons of tin. Another factor of interest comes from the lead industry. This business constitutes one of the largest consumers of tin, the leading company alone taking ten million dollars worth per annum, for use in the manufacture of solder, type metals, babbitt metal, etc. The lead trust already has a plant in the neighborhood of the projected tin smelter, and is now about to make rge additions, with a view to ultimately using on the spot as large a percentage of the smelter's output as possible. We have here an admirable illustration, not only of the way in which such undertakings as the Panama Canal affect the whole business structure of the world to our advantage, but of the lengths to which modern industry is prepared to go in its efforts to cut out the transportation factor.

\section{The National Library of Siam}

THE American vice-consul at Bangkol reports the formal reopening, by the King of Siam, of the National Library, which has just moved into new and spacious quarters. This library was established in 1881 by the children of Kin Mongkut, as a memorial to their father, and it was formerly called the Vajirana Library. In 1904 it became the depository for the national archives of the kingdom, and also for the religious archives and it was put under the and also for the religious archives and it was rian the care of an eminent orientalist as chief librarelions for Thai or Siamese literature, and a third for foreig literature Ancient manuscipts in Bali and Thai have been gathered from Buddhist monasteies throughout the country, and more than 100,000 of them have been placed in the library. From time to time selected manuscripts are published by the library, more than 100 of these having already been issued. Lastly, the National Library has an important collection of ancient inscriptions on stone.

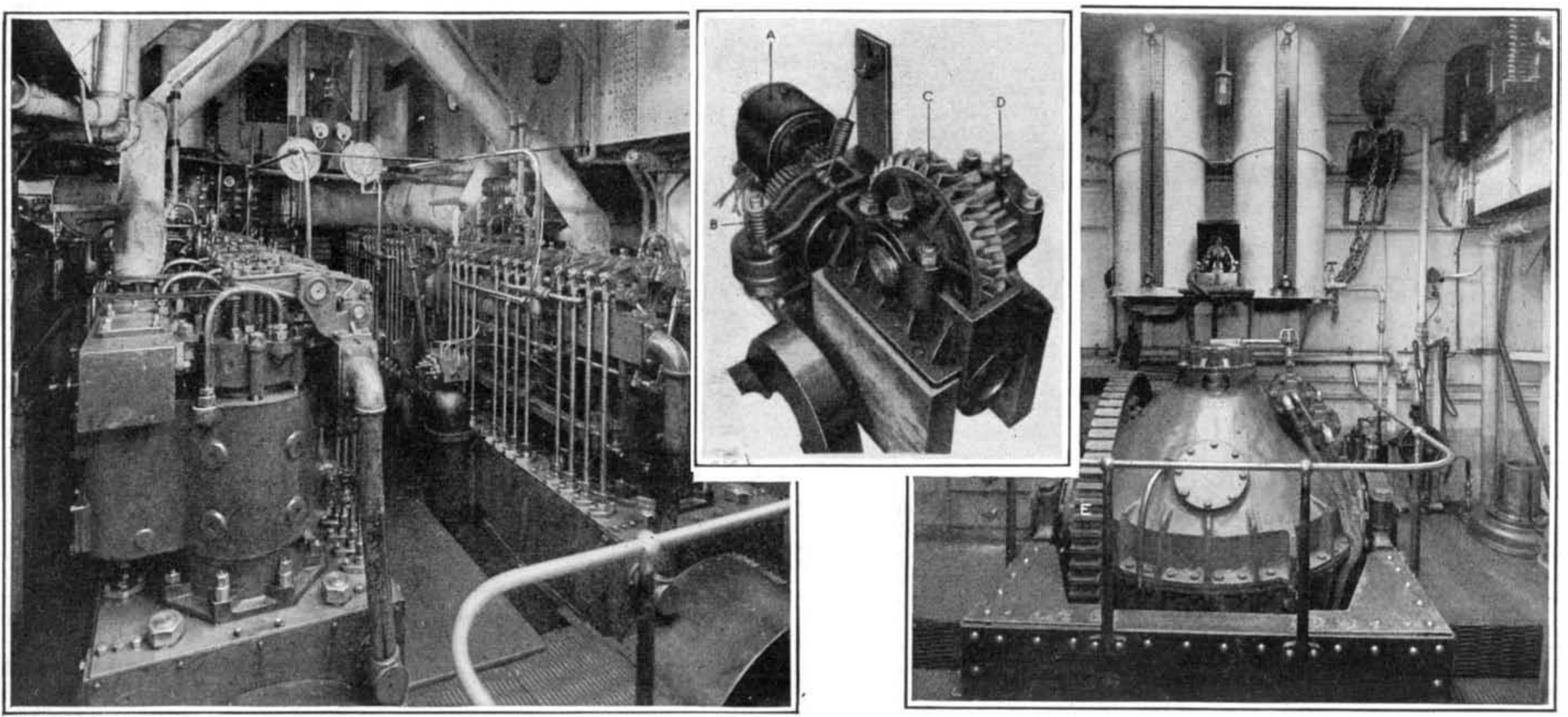

The Diesel engine plant of the Yacht "Aramis" and the gyroscopic stabilizer. The insert sliows the precession unit of the stabilizer 